\title{
Soil properties and microbial ecology of a paddy field after repeated applications of domestic and industrial sewage sludges
}

\author{
Xiaoyan Liu ${ }^{1,2}$ - Wuxing Liu ${ }^{1}$ Qingling Wang ${ }^{1}$ Longhua $\mathrm{Wu}^{1}$ - Yongming Luo ${ }^{1,3}$. \\ Peter Christie $^{1}$
}

Received: 1 December 2016 / Accepted: 1 February 2017 / Published online: 14 February 2017

(C) Springer-Verlag Berlin Heidelberg 2017

\begin{abstract}
The effects of repeated application of two types of sewage sludge, domestic and industrial (petrochemical, PSS) sludges, into paddy fields over a 5-year period on the soil properties and microbial ecology were studied and compared with conventional NPK fertilizer application. Soil organic matter and total nitrogen contents were significantly higher in the two sludge treatments than that in fertilized plots after 5 years. Soil concentrations of potentially toxic metals were low after 5 years of both sludge treatments, but the polycyclic aromatic hydrocarbons (PAHs) showed differences between the two sludge types. Concentrations of high-molecularweight PAHs were significantly higher $(p<0.05)$ in the petrochemical sludge treatment than the domestic sludge treatment or the fertilizer control, although the total concentrations of 16 types of PAH in the petrochemical sludge treatment were only slightly higher than in the domestic sludge treatment and the control. The biological toxicity of soil dimethyl sulfoxide extracts from the petrochemical sludge treatment was also significantly higher $(p<0.05)$ than those from the fertilizer control and the domestic sludge treatment when evaluated using Photobacterium phosphoreum T3. Both types of sewage sludge increased soil microbial activity, but only the petrochemical sludge led to enrichment with specific PAH
\end{abstract}

Responsible editor: Zhihong Xu

Wuxing Liu

liuwuxin@issas.ac.cn

1 Key Laboratory of Soil Environment and Pollution Remediation, Institute of Soil Science, Chinese Academy of Sciences, Nanjing 210008, China

2 University of Chinese Academy of Sciences, Beijing 100049, China

3 Institute of Coastal Zone Research, Chinese Academy of Sciences, Yantai 264003, China degraders such as Mycobacterium, Nocardioides, and Sphingomonas.

Keywords Sludge application · Industrial sludge $\cdot$ Polycyclic aromatic hydrocarbons $\cdot$ Biological toxicity $\cdot$ Microbial activity $\cdot$ Paddy soil

\section{Introduction}

Sewage sludge consists of by-products of wastewater treatment processes. It is an inevitable and complex mixture that is removed from wastewater coming from various sources (domestic sewage, industries) and rainwater runoff from roads, through physical, biological, and/or chemical treatments (Usman et al. 2012). Due to the increasing amount of sewage sludge produced as a consequence of the rapidly increasing number of wastewater treatment plants in China, the various types of hazardous substances in sewage sludges have become an important environmental issue. Until now, the main disposal routes of sewage sludges include stacking in the open, landfilling, incineration, and land application (Fullana et al. 2004; Stasta et al. 2006; Chen et al. 2012). Of these, the traditional treatment methods of stacking in the open and landfill remain the most frequently used treatments. However, landfill sites can be unstable and piles of sludge would become to potential pollution sources ( $\mathrm{Li}$ et al. 2008). Incineration can achieve significant dry solid volume reduction and energy recovery from the sludge, but atmospheric pollution and high cost may hinder its use (Chen et al. 2012). Land application is currently more sustainable than above methods for the final disposal of sewage sludge. Because of its organic matter content, plant-available nutrients and its low-cost, agricultural application of sewage sludge has become an economical, efficient, and increasingly popular 
method (Asagi and Ueno 2008; Singh and Agarwal 2008; Wang et al. 2008; Mahapatra et al. 2013). About $60 \%$ of sewage sludge produced in the US are reused by application to agricultural land (National Research Council 2002). Use of sludges in agriculture is also a widely used method in many European countries such as Portugal, the UK, Iceland, and Spain (Kelessidis and Stasinakis 2012).

The properties of sewage sludge depend on the source of the wastewater and the treatment process used in any particular localized wastewater treatment plant (Cai et al. 2007). In general, sewage sludge can promote soil fertility and plant growth; some sludges, especially coming from wastewater treatment plants serving both domestic and industrial areas, can contain a range of hazardous substances which might have negative environmental effects (Singh and Agarwal 2008; Li et al. 2008). The land application of sludge involves effects on soil properties, soil microbes, plants, and animal by the accumulation of these pollutants. This may threaten the safety of agricultural production and human health through the food chain (Pritchard et al. 2010; Bondarczuk et al. 2016; Harder et al. 2016). Thus, the use of sewage sludge as a source of plant nutrients for crop production needs to be carried out carefully to protect the environment and human health. Numerous studies have reported that sewage sludges potentially carry pollutants such as potentially toxic metals (HMs) (Fliessbach et al. 1994; Witter et al. 2000; Udom et al. 2004; Liu and Sun 2013b; Cheng et al. 2014) and persistent organic pollutants (POPs) including polycyclic aromatic hydrocarbons (PAHs) (Oleszczuk and Baran 2005, Oleszczuk 2006; Li et al. 2008; Liu et al. 2013a). Trace metals have led to considerable concern for many years, but information on the effects of PAHs from sewage sludges on the properties and microbial ecology of agricultural soils is incomplete. PAHs have mutagenic and carcinogenic properties (IARC 1983), and their accumulation in soils may exert a considerable impact on soil microbial community structure and diversity, and this has become a topic of major concern.

The current study was conducted to investigate the potential effects of repeated applications of sewage sludge to a paddy field over 5 years on (1) soil properties and the accumulation of the major pollutants, (2) soil biological toxicity and activity, and (3) changes in the microbial community of the paddy soil. Two contrasting types of sewage sludge were used, a domestic sewage sludge (DSS) and an industrial, petrochemical sewage sludge (PSS).

\section{Materials and methods}

\section{Experimental site and fertilization treatments}

The sludge continuous application experiment in paddy field was carried out for 5 years at Suzhou Academy of Agricultural
Sciences Experimental Station ( $\left.31^{\circ} 3^{\prime \prime} \mathrm{N}, 120^{\circ} 6^{\prime \prime} \mathrm{E}\right)$ in east China. The soil tested was classified as a Typic Hapli-Stagnic Anthrosols according to the Food and Agriculture Organization soil classification system. The treatments were arranged in a randomized complete block design with four replicates, and each plot was $3.0 \mathrm{~m} \times 4.5 \mathrm{~m}$. The site was used to grow a continuous paddy rice and wheat rotation. There were three treatments amended with (1) NPK fertilizer (CF), (2) DSS, and (3) PSS. The domestic sewage sludge was sourced from Fuxing municipal wastewater treatment plant in Suzhou, Jiangsu province, East China, and the petrochemical sewage sludge was obtained from the wastewater treatment plant at Jingmen petrochemical enterprise, Hubei province, central China. Selected physico-chemical properties and metal and PAH contents of both sewage sludges are given in Table 1 . Compound NPK fertilizers were applied at a rate of $0.5 \mathrm{~kg}$ (dry weight) per plot per 6 months. Both types of sludge were applied at a rate of $4 \mathrm{~kg}$ (dry weight) per plot per 6 months. Plots receiving the sludge applications also received appropriate amounts of N, P, K to give the same total application rates of these major nutrients as in the CF control plots. The fertilizers and sludges were all surface applied as basal nutrient applications before each crop was sown.

\section{Soil sampling}

Soil sampling was conducted after the harvest of the fifth rice crop in October 2015. Soil samples were collected randomly from the top $20 \mathrm{~cm}$ of the soil profile across each plot, with five replicate samples taken from each plot and combined to give a composite sample. Stones and plant root residues were discarded and each soil sample was divided into three parts, one of which was stored at $4{ }^{\circ} \mathrm{C}$ prior to analysis for microbial activities. The second portion was stored at $-70{ }^{\circ} \mathrm{C}$ prior to soil DNA extraction, and the third was freeze-dried and passed through a 60-mesh sieve for further analysis.

\section{Effect of different nutrient applications on selected soil physico-chemical properties and PAH concentrations}

Soil electric conductivity (EC) was determined with a conductivity meter (Leici DDS-307, Shanghai, China) in a 1:5 suspension in $\mathrm{H}_{2} \mathrm{O}$. Other soil physico-chemical properties, namely $\mathrm{pH}$, organic matter $(\mathrm{OM})$ content, total nitrogen (TN), total phosphorus (TP), and total potassium (TK) were determined using the method according to $\mathrm{Lu}$ (1999).

Sixteen priority PAHs listed by the US Environmental Protection Agency (EPA) were analyzed. Contents of PAHs in soil were determined as follows. Freeze-dried soil (2.0 g mixed with $2 \mathrm{~g}$ anhydrous sodium sulfate) was weighed and placed in a Soxhlet apparatus prior to cleanup using $70 \mathrm{~mL}$ dichloroethane solvent for $24 \mathrm{~h}$ at $54{ }^{\circ} \mathrm{C}$. The solvents were removed by rotary evaporation until the eluent was finally 
Table 1 Selected physico-chemical properties and potentially toxic metal contents of the two types of sewage sludge (dry weight basis)

\begin{tabular}{llllllllll}
\hline Sludge & $\mathrm{pH}$ & $\begin{array}{l}\mathrm{MC} \\
(\%)\end{array}$ & $\begin{array}{l}\mathrm{OM} \\
\left(\mathrm{g} \mathrm{kg}^{-1}\right)\end{array}$ & $\begin{array}{l}\mathrm{TN} \\
\left(\mathrm{g} \mathrm{kg}^{-1}\right)\end{array}$ & $\begin{array}{l}\mathrm{TP} \\
\left(\mathrm{g} \mathrm{kg}^{-1}\right)\end{array}$ & $\begin{array}{l}\mathrm{TK} \\
\left(\mathrm{g} \mathrm{kg}^{-1}\right)\end{array}$ & $\begin{array}{l}\mathrm{Zn} \\
\left(\mathrm{mg} \mathrm{kg}^{-1}\right)\end{array}$ & $\begin{array}{l}\mathrm{Cu} \\
\left(\mathrm{mg} \mathrm{kg}^{-1}\right)\end{array}$ & $\begin{array}{l}\mathrm{Cd} \\
\left(\mathrm{mg} \mathrm{kg}^{-1}\right)\end{array}$ \\
\hline $\begin{array}{l}\text { Domestic sewage sludge } \\
\begin{array}{l}\text { Petrochemical sewage } \\
\text { sludge }\end{array}\end{array}$ & 6.23 & 81.5 & 463 & 46.8 & 11.00 & 14.40 & 799 & 143.0 & 1.79 \\
\hline
\end{tabular}

$M C$ moisture content, $O M$ organic matter, $T N$ total nitrogen, $T P$ total phosphorus, $T K$ total potassium, PAHs polycyclic aromatic hydrocarbons

evaporated to dryness and then dissolved in $2 \mathrm{~mL}$ cyclohexane. Then, $0.5-\mathrm{ml}$ aliquots of the cyclohexane extracts were cleaned up using a $0.5 \mathrm{~cm}$ (i.d.) $\times 20 \mathrm{~cm}$ column consisting of $1 \mathrm{~g}$ silica gel (baked at $400{ }^{\circ} \mathrm{C}$ for $8 \mathrm{~h}$ in a muffle furnace) activated for $15 \mathrm{~min}$ with $10 \mathrm{~mL} n$-hexane and capped with anhydrous sodium sulfate. The column was then washed with a mixture of dichloromethane and $n$-hexane $(1: 1 \mathrm{v} / \mathrm{v})$, and the first $1 \mathrm{~mL}$ of washings was discarded. Finally, the remainder ( $2 \mathrm{~mL}$ washed solution) was evaporated to dryness under a gentle steam of pure $\mathrm{N}_{2}$ gas and dissolved in $2 \mathrm{~mL} n$-hexane for gas chromatography-mass spectrometry (GC-MS) analysis of PAHs.

The GC-MS was equipped with a capillary column (Restek, Bellefonte, PA) DB-5ms ( $30 \mathrm{~m} \times 0.25 \mathrm{~mm}$ i.d., film thickness $0.25 \mu \mathrm{m}$ ), with helium as the carrier gas at a flow rate of $1 \mathrm{~mL} \mathrm{~min}{ }^{-1}$, using selective ion monitoring (SIM) mode to detect PAHs The scan ions ranged from 127 to 279 a.m.u., and the dwell time per ion was $10 \mathrm{~ms}$. The oven temperature was held at $50^{\circ} \mathrm{C}$ for $1 \mathrm{~min}$, increased to $200{ }^{\circ} \mathrm{C}$ at a rate of $25^{\circ} \mathrm{C} \mathrm{min}^{-1}$, and increased to $280{ }^{\circ} \mathrm{C}$ at a rate of $8{ }^{\circ} \mathrm{C} \mathrm{min}{ }^{-1}$, then increased to $283{ }^{\circ} \mathrm{C}$ at a rate of $1{ }^{\circ} \mathrm{C} \mathrm{min}^{-1}$, and finally increased to $290^{\circ} \mathrm{C}$ at a rate of $2{ }^{\circ} \mathrm{C} \mathrm{min}^{-1}$ and held for $5 \mathrm{~min}$, and the last-run application was run for $2 \mathrm{~min}$ at $295^{\circ} \mathrm{C}$. The injector temperature was $280{ }^{\circ} \mathrm{C}$. Prepared sample was injected with an autoinjector. The injection volume was $1 \mu \mathrm{L}$ in a splitless mode. All peaks of the PAHs studied were eluted between 5 and $20 \mathrm{~min}$. Identification and quantification of the 16 PAHs were based on matching their retention time with a mixture of PAH standards. Solvent blanks and duplicate samples were also analyzed and the variation in PAH concentrations of replicate samples was $<10 \%$. The limit of detection (LOD), defined as the standard deviation from the mean blank $(n=3)$, ranged from 8 to $12 \mu \mathrm{g} \mathrm{kg}^{-1}$. SIM mode was carried out using the molecular ions selective for the individual PAHs. Chromatographic data were collected and processed using Chemstation (Teng et al. 2011; Hou et al. 2015).

\section{Biological toxicity test}

The acute toxicity assays for soil samples were carried out by luminescent bacteria, which are expressed in terms of relative luminosity. Freeze-dried Photobacterium phosphoreum T3 powder was supplied by Nanjing Institute of Soil Science, Chinese Academy of Sciences. P. phosphoreum T3 was resuscitated in $1 \mathrm{~mL} \mathrm{3 \%} \mathrm{NaCl}$ solution and stored in an ice water bath prior to the acute toxicity assay. Activated bacterial suspension $(10 \mu \mathrm{L})$ was then placed in a test tube containing $2 \mathrm{~mL} \mathrm{3 \%} \mathrm{NaCl}$ solution. The test bottle was mixed thoroughly and placed in a Microtox DXY-2 Toxicity Analyzer (Modern Water, New Castle, DE). The scale of initial luminosity was in the range $600-1900 \mathrm{mV}$. Freshly prepared freeze-dried P. phosphoreum $\mathrm{T} 3$ powder was used if the initial luminosity did not reach the standard. The laboratory temperature was set at $20-25{ }^{\circ} \mathrm{C}$ (Ding et al. 2015). Water and dimethyl sulfoxide (DMSO) extracts of soil were prepared for the toxicity tests. Aliquots of $5 \mathrm{~g}$ soil (dry weight) were extracted by sonication for $30 \mathrm{~min}$ in $5 \mathrm{~mL}$ deionized water at room temperature, the mixture was centrifuged, and the supernatant was used within $48 \mathrm{~h}$. Five grams of soil was extracted for $16 \mathrm{~h}$ in a Soxhlet extractor with $60 \mathrm{~mL}$ dichloroethane at $54{ }^{\circ} \mathrm{C}$, the extract was reduced to $5 \mathrm{~mL}$ in a rotary evaporator, and then $5 \mathrm{~mL}$ exchange solvent DMSO was added and the mixture was evaporated under reduced pressure to $5 \mathrm{~mL}$. The water or DMSO extracts $(40 \mu \mathrm{L})$ and $40 \mu \mathrm{L}$ of the activated bacterial suspension were transferred into tubes containing $2 \mathrm{~mL} 3 \% \mathrm{NaCl}$ solution. After exposure for $15 \mathrm{~min}$, the individual toxicity values were recorded using the analyzer. The relative luminosity was calculated by the mean luminescence in the samples and the mean luminescence in the controls (without extracts). The relative luminosity (RL) was calculated according to Eq. (1)

$\mathrm{RL}(\%)=\left(\frac{L_{\text {sample }}}{L_{\text {blank }}}\right) \times 100 \%$

where $L$ is the luminosity (Ding et al. 2015).

\section{Microbial community-level physiological profiling analysis}

Biolog Eco plates were used to study the substrate utilization pattern of soil microbial communities. An aliquot of $10 \mathrm{~g}$ fresh soil was shaken with $100 \mathrm{~mL}$ of autoclave-sterilized saline solution for $30 \mathrm{~min}, 10^{-3}$ serial dilutions were prepared and poured into sterile pipette trays, and $150 \mathrm{~mL}$ was inoculated into each well of the microplates with an eight-channel 
pipettor at $25{ }^{\circ} \mathrm{C}$. The plates were scanned every $12 \mathrm{~h}$ at $590 \mathrm{~nm}$ for 7 days using a Biolog automated plate reader. All wells were blanked to the control wells (Liu et al. 2016). The Biolog data were used for calculating average well color development (AWCD) and AWCD was calculated according to Eq. (2)

$\mathrm{AWCD}=\frac{\sum_{i=1}^{31}\left(C_{i}-R\right)}{31}$

where $C_{i}$ is the optical density of each cultured well, and $R$ is the optical density of control well (Garland and Mills 1991).

\section{Soil DNA extraction and PCR amplification}

The effects of repeated land applications of sludge on soil bacterial diversity were evaluated by extracting microbial DNA from $0.5 \mathrm{~g}$ of soil from each replicate plot of the three treatments using a soil DNA kit (Fast DNA SPIN for soils, MP Biomedicals, Solon, $\mathrm{OH}$ ) according to the manufacturer's protocols. The bacterial primers targeting the variable V4-V5 region of the bacterial $16 \mathrm{~S}$ ribosomal RNA (rRNA) gene were used to amplify fragments. Initial PCR amplification was done using primers 515F 5'-barcode-GTGCCAGCMGCCGCGG$3^{\prime}$ and 907R 5'-CCGTCAATTCMTTTRAGTTT-3', where the barcode is an eight-base sample-specific sequence, primers in a total volume of $20 \mu \mathrm{L}$, containing $4 \mu \mathrm{L}$ of $5 \times$ FastPfu PCR buffer, $2 \mu \mathrm{L}$ of $2.5 \mathrm{mM}$ dNTPs, $0.8 \mu \mathrm{L}$ of each primer $(5 \mu \mathrm{M}), 5 \mu \mathrm{g}$ BSA, $0.4 \mu \mathrm{L}$ of FastPfu DNA polymerase, and $10 \mathrm{ng}$ DNA as the template. After initial denaturation at $95{ }^{\circ} \mathrm{C}$ for $2 \mathrm{~min}$, the reactions were run for 25 cycles of $95^{\circ} \mathrm{C}$ for $30 \mathrm{~s}$ and $72{ }^{\circ} \mathrm{C}$ for $30 \mathrm{~s}$ with a final elongation step at $72{ }^{\circ} \mathrm{C}$ for $5 \mathrm{~min}$ (Hou et al. 2015). Sequencing was conducted by Majorbio Bio-pharm Technology Co., Ltd. (Shanghai, China).

\section{Processing of pyrosequencing data}

Sequence reads were trimmed with Trimmomatic, and then reads were assembled with Flash software for further analysis by Mothur 1.33.0 (Hou et al. 2015). Unique sequences were aligned to the reference Silva database by default settings, and chimeric sequences were removed. Sequences passing these screens were classified using a ribosomal database project naïve Bayesian rRNA classifier with a confidence of $80 \%$. At each taxonomic level, the proportion of sequence identities was calculated as a percentage of all sequences classified in that sample. Operational taxonomic units (OTUs) were classified at similarities of $97 \%$ after normalized to 8698 sequences per sample. The a-diversity indices, including observed OTUs (Sobs), InvSimpson, and Shannon, were calculated using Mothur (Schloss et al. 2009).

\section{Statistical analysis}

Statistical analysis was carried out using the SPSS 22.0 for Windows software package. Data were subjected to one-way analysis of variance and mean values were compared using Duncan's new multiple range test at the 5\% level using the SPSS statistical package.

\section{Results}

Effect of application of different sludge types on soil physico-chemical properties and metal contents

Soil $\mathrm{pH}, \mathrm{EC}, \mathrm{OM}, \mathrm{TN}, \mathrm{TP}, \mathrm{TK}$, and three potentially toxic metals $(\mathrm{Zn}, \mathrm{Cu}, \mathrm{Cd})$ in the three treatments are shown in Table 2. Soil $\mathrm{pH}$ values ranged from 5.62 to 5.95 , soil total $\mathrm{K}$ content showed no significant differences among the three experimental treatments $(p<0.05)$, and all samples contained similar concentrations of the three metals $(\mathrm{Cd}, \mathrm{Zn}, \mathrm{Cu})$. Moreover, the soil from plots receiving domestic sludge had the highest levels of phosphorus, and the soil EC value and soil OM and TN contents after both types of sludge application area were all significantly higher than that in the control soils $(p<0.05)$.

\section{Effect of application of different sludge types on soil PAH contents}

The final mean soil concentrations of 16 PAHs were $1.904 \pm 0.243 \mathrm{mg} \mathrm{kg}^{-1}$ in the fertilized control plots, $1.799 \pm 0.109 \mathrm{mg} \mathrm{kg}^{-1}$ in the plots receiving domestic sludge, and $2.495 \pm 0.481 \mathrm{mg} \mathrm{kg}^{-1}$ in the plots receiving petrochemical sludge, all on a dry weight basis after 5 years of repeated sewage sludge application. There were no differences among treatments in soil total PAH contents. However, petrochemical sludge application significantly increased the soil contents of high-molecular-weight PAHs with five and six rings, including benzo[b]fluoranthene $(\mathrm{BbF})$, benzo[k,j]fluoranthene (BkF), benzo[a]pyrene (BaP), indeno[1,2,3]pyrene (InP), dibenzo[a,h]anthracene (DBA), and benzo[ghi]perylene $(\mathrm{BgP})$ compared with the fertilizer control (Fig. 1).

\section{Biological toxicity of tested soil}

The bacterium $P$. phosphoreum T3 can produce bioluminescence which will decrease with the addition of inhibitory toxicants. In the assay, the level of inhibition is higher when the relative luminosity is lower, i.e., when the test solution has higher toxicity. Figure 2 shows that there were no significant differences in relative luminosity value between the water extracts of soil samples from two sludge application treatments and those from the chemical fertilizer treatment. 
Table 2 Effects of different types of sewage sludge on soil physicochemical properties and potentially toxic metal contents (dry weights)

\begin{tabular}{llll}
\hline Property & Fertilizer control & Domestic sludge & Industrial sludge \\
\hline $\mathrm{pH}$ & $5.95 \pm 0.13 \mathrm{a}$ & $5.62 \pm 0.11 \mathrm{~b}$ & $5.93 \pm 0.09 \mathrm{a}$ \\
$\mathrm{EC}\left(\mu \mathrm{S} \mathrm{cm}^{-1}\right)$ & $156.80 \pm 2.34 \mathrm{~b}$ & $221.50 \pm 16.26 \mathrm{a}$ & $194.25 \pm 19.45 \mathrm{a}$ \\
$\mathrm{OM}\left(\mathrm{g} \mathrm{kg}^{-1}\right)$ & $32.02 \pm 1.01 \mathrm{~b}$ & $38.72 \pm 3.42 \mathrm{a}$ & $37.55 \pm 1.36 \mathrm{a}$ \\
$\mathrm{TN}\left(\mathrm{g} \mathrm{kg}^{-1}\right)$ & $0.89 \pm 0.15 \mathrm{~b}$ & $1.25 \pm 0.16 \mathrm{a}$ & $1.15 \pm 0.08 \mathrm{a}$ \\
$\mathrm{TP}\left(\mathrm{g} \mathrm{kg}^{-1}\right)$ & $1.19 \pm 0.08 \mathrm{~b}$ & $2.07 \pm 0.31 \mathrm{a}$ & $1.32 \pm 0.06 \mathrm{~b}$ \\
$\mathrm{TK}\left(\mathrm{g} \mathrm{kg}^{-1}\right)$ & $14.08 \pm 0.45 \mathrm{a}$ & $14.70 \pm 0.51 \mathrm{a}$ & $14.20 \pm 0.31 \mathrm{a}$ \\
$\mathrm{Zn}\left(\mathrm{mg} \mathrm{kg}^{-1}\right)$ & $99.79 \pm 5.99 \mathrm{ab}$ & $105.69 \pm 8.31 \mathrm{a}$ & $92.32 \pm 2.86 \mathrm{~b}$ \\
$\mathrm{Cu}\left(\mathrm{mg} \mathrm{kg}^{-1}\right)$ & $37.46 \pm 3.28 \mathrm{a}$ & $41.33 \pm 2.67 \mathrm{a}$ & $40.13 \pm 2.59 \mathrm{a}$ \\
$\mathrm{Cd}\left(\mathrm{mg} \mathrm{kg}^{-1}\right)$ & $0.19 \pm 0.02 \mathrm{a}$ & $0.18 \pm 0.02 \mathrm{a}$ & $0.16 \pm 0.02 \mathrm{a}$ \\
\hline
\end{tabular}

Each treatment comprised four replicates. Data are expressed as mean \pm standard error. Different letters indicate statistically significant difference at $p<0.05$ by analysis of variance

$E C$ electric conductivity

However, the relative luminosity of the DMSO soil extract from the petrochemical sludge treatment was significantly lower than the others $(p<0.05)$, and in the case of the organic extracts, the biological toxicity values for the different treatments were in the sequence petrochemical sludge $>$ fertilizer control $>$ domestic sludge.

\section{Substrate utilization by soil microorganisms}

The activity of the soil microbial community evaluated by AWCD is shown in Fig. 3. There was no apparent lag in the first $24 \mathrm{~h}$, and subsequently, the AWCD always increased with time until $168 \mathrm{~h}$, indicating that all three treatments were capable of metabolizing the organic substrates in the Biolog Eco

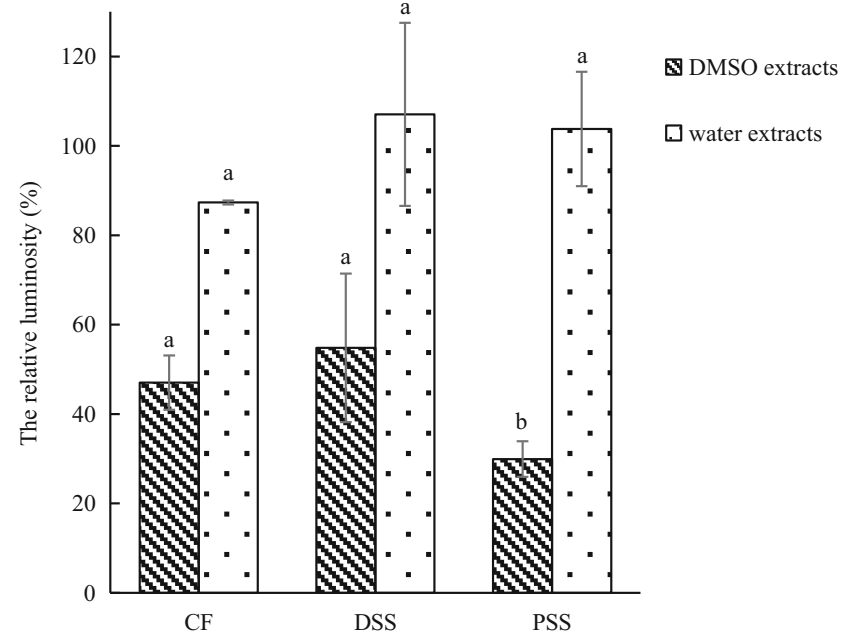

Fig. 2 The relative luminosity of soil extract from the different treatments. Vertical bars represent standard deviation $(n=4)$. Different letters on columns indicate statistically significant difference at $p<0.05$ by analysis of variance

plates. Although no differences in AWCD were observed within the first $24 \mathrm{~h}$, the AWCD value was always higher in the domestic sludge-treated soil than in the petrochemical sludge treatment or fertilizer control with further increase in incubation time. After $96 \mathrm{~h}$, the absorbance of the fertilizer control showed a slightly lower value than the two sludge types. The overall trend of AWCD after $96 \mathrm{~h}$ was domestic sludge $>$ petrochemical sludge $>$ fertilizer control (Fig. 3).

\section{Bacterial community composition and diversity}

In total, approximately 167,472 sequence reads of the $16 \mathrm{~S}$ rRNA gene were obtained after a sequence optimization
Fig. 1 Distribution of PAHs with different ring numbers in different soil samples. Vertical bars represent standard deviation $(n=4)$. Different letters on columns indicate statistically significant difference at $p<0.05$ by analysis of variance

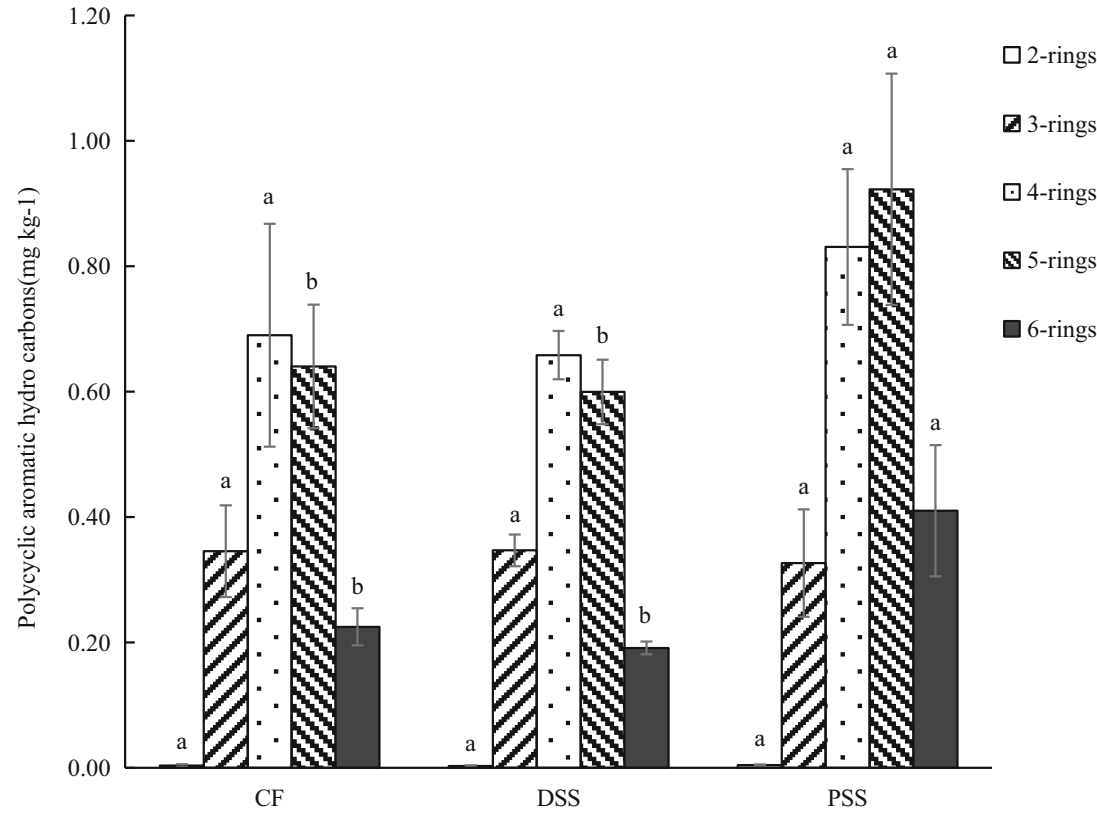


Fig. 3 Variation in average well color development (AWCD) of soil samples over time in the Biolog Eco plates

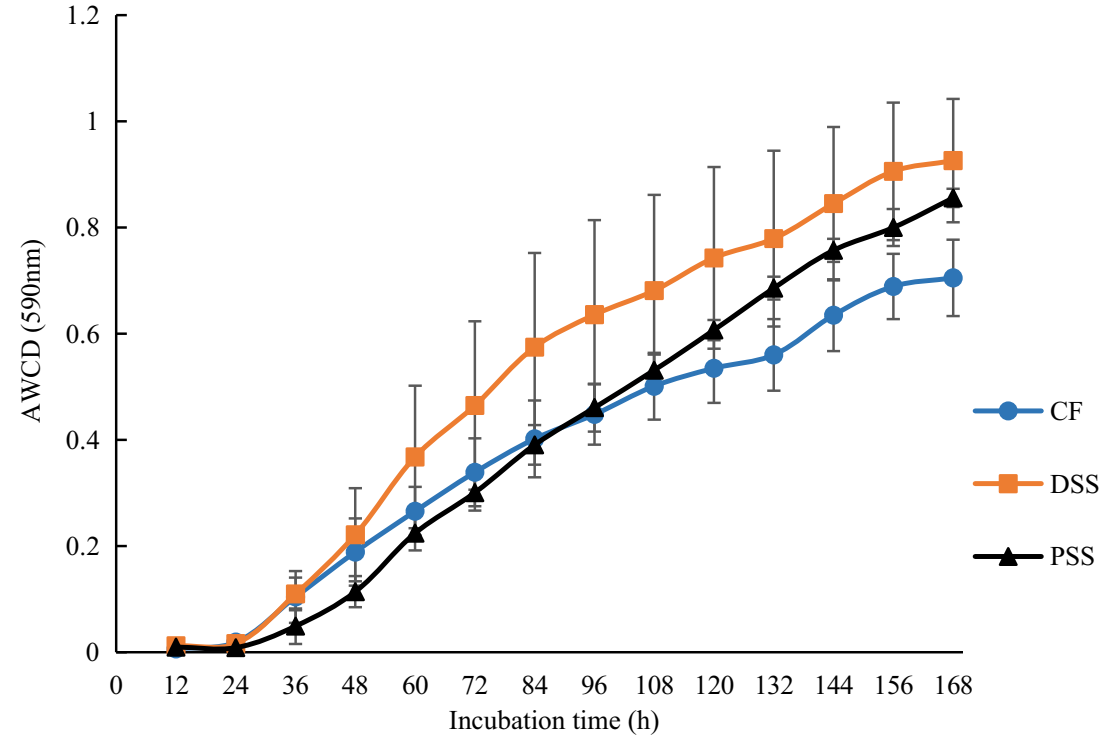

process with an average number of 13,956 sequences per sample (ranging from 8698 to 18,159). A total of 8698 reads were subsampled from each replicate for further analysis. A 97\% similarity cutoff was used to delineate OTUs in the downstream analyses. The structure of the microbial communities in the soil samples from the three treatments was compared at phylum level (Fig. 4). Proteobacteria, Actinobacteria, Chloroflexi, and Actinobacteria were the most prevalent phyla except for the unclassified group, but the overall bacterial composition of the different treatments at phylum level was very similar. The calculated bacterial community richness and diversity indices also showed no significant differences in Sobs, InvSimpson, and Shannon indexes in the different treatments (Table 3). Furthermore, Fig. 5 reveals visible effects on some individual genera, and the relative abundances were significantly different between the fertilizer control
Fig. 4 The frequencies of sequences over phylum level as affected in the soil of the fertilizer control $(C F)$, domestic sludge $(D S S)$, and petrochemical sludge (PSS). Phyla that comprise $<0.5 \%$ of the bacteria and archaea in all treatments are grouped into "others." Sequences that could not be classified into any known group are designated "unclassified"

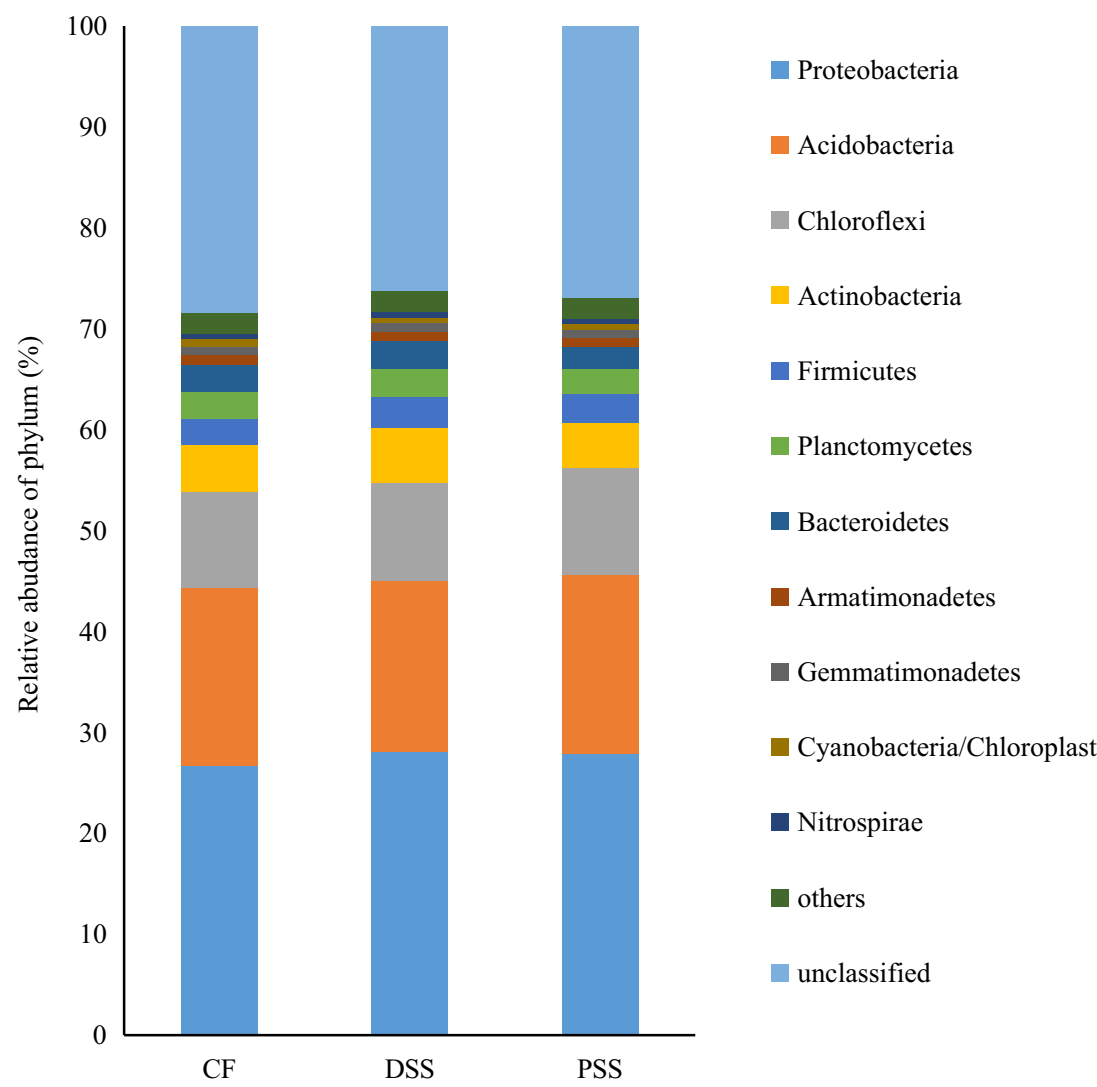


Table 3 The diversity indices of the soil bacterial community in the different treatments

\begin{tabular}{llll}
\hline Treatment & Sobs & InvSimpson & Shannon \\
\hline Fertilizer control & $5709 \pm 98 \mathrm{a}$ & $383 \pm 28 \mathrm{a}$ & $7.35 \pm 0.04 \mathrm{a}$ \\
Domestic sludge & $5613 \pm 373 \mathrm{a}$ & $382 \pm 32 \mathrm{a}$ & $7.33 \pm 0.12 \mathrm{a}$ \\
Industrial sludge & $5603 \pm 357 \mathrm{a}$ & $382 \pm 17 \mathrm{a}$ & $7.31 \pm 0.08 \mathrm{a}$ \\
\hline
\end{tabular}

Different letters indicate statistically significant difference at $p<0.05$ by analysis of variance

application area and the petrochemical sludge application area, such as Desulfomonile, Mycobacterium, Nocardioides, and Sphingomonas.

\section{Discussion}

The application of sewage sludges to agricultural soils is a common practice worldwide. The results of the present study indicate that application of sludge can increase or maintain soil fertility. Soil organic matter and N and P contents following sewage sludge application were significantly higher than after application of chemical fertilizer (Table 2), and this is in accord with previous reports (Su et al. 2007; Roig et al. 2012; Wu et al. 2012). Large amounts of nutrients such as organic matter and organic and inorganic $\mathrm{N}$ and $\mathrm{P}$ in the sludges as shown in Table 1, especially the domestic sewage sludge, may improve and maintain soil quality (Table 2).

However, numerous studies have shown that metals and PAHs are important pollutants in sludges (Li et al. 2008;
Duan et al. 2015; Mardan et al. 2015). The soil metal contents after sludge application in the present study did not exceed the standards ( $\mathrm{Zn}, 200 \mathrm{mg} \mathrm{kg}^{-1} ; \mathrm{Cu}, 50 \mathrm{mg} \mathrm{kg}^{-1} ; \mathrm{Cd}, 0.3 \mathrm{mg} \mathrm{kg}^{-1}$ ) determined by the Chinese Environmental Quality Standard for Agricultural Soils (Table 3). We are therefore more concerned with the changes in soil PAH contents in the current study. The soil contents and composition of PAHs differed and depended mainly on the type of sludge applied. Although the highest PAH contents were found in soils treated with petrochemical sludge, there were no significant differences among treatments. The distribution of PAHs with different ring numbers (Fig. 1) indicates that the soil contents of high-molecularweight PAHs were significantly higher $(p<0.05)$ in the petrochemical sludge treatment than the control or domestic sludge treatments. Previous studies have also shown that PAHs from sludge, and especially high-molecular-weight PAHs, can accumulate in paddy soils for long periods of time (Lichtfouse et al. 2005). PAHs with five- and six-ring structures have greater carcinogenic potential than those with two-, three-, or four-ring structures (Boonchan et al. 2000). As a result, the concentration of PAHs may continue to increase with further use of sewage sludges and this may pose a threat to crop production and environmental safety in agriculture soils.

Although chemical-based analytical methods can be used to determine the levels of contaminants, they cannot provide detailed information about effects on soil biology and soil quality (Liu et al. 2007). The biological toxicity test has often been used to analyze the potential effects of toxic chemicals in water or soil on bacteria using luminous bacteria and is based on the fact that bacteria are an integral part of the ecosystem.
Fig. 5 The relative abundance of $C F, D S S$, and PSS treatments at genus level. Vertical bars represent standard deviation $(n=4)$. Different letters on columns indicate statistically significant difference at $p<0.05$ by analysis of variance

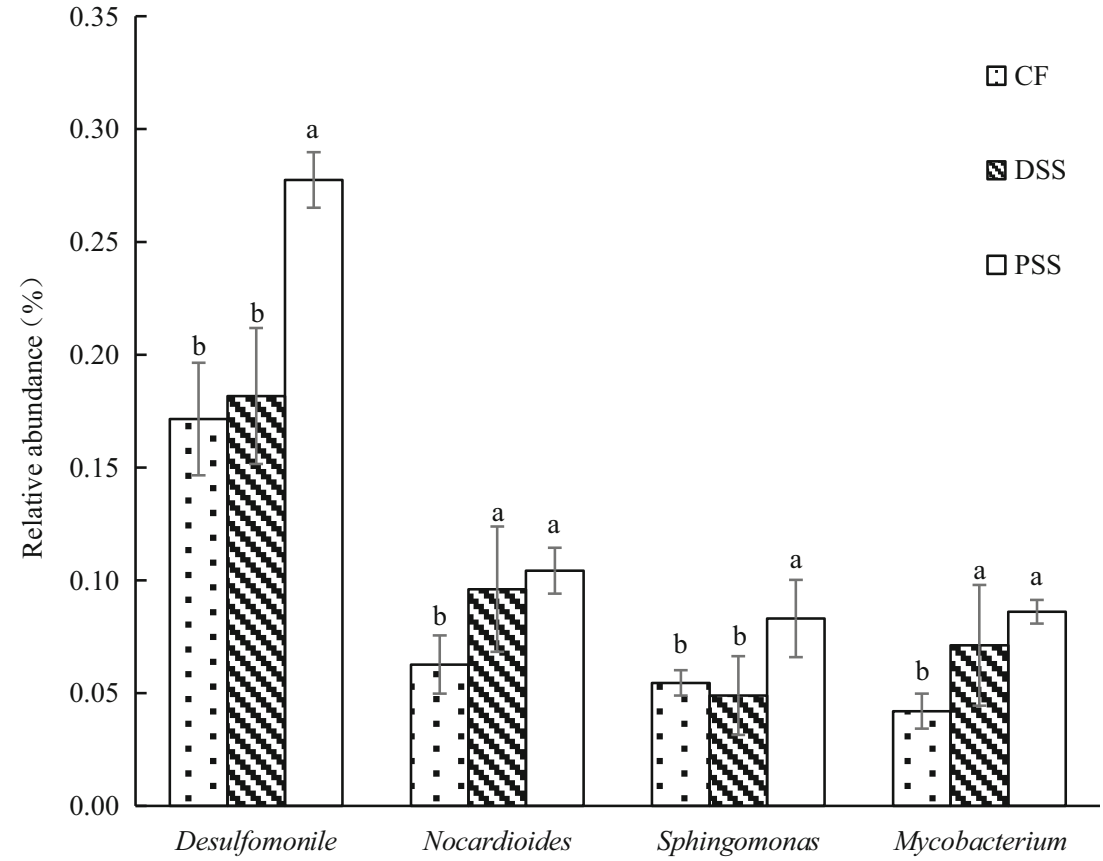


The method is also rapid, easy to perform, sensitive, and costeffective (Ulitzur et al. 2002). In the present study, luminescence was not inhibited by water extracts of two sewage sludge treatments but was slightly increased by water extracts. Electrical conductivity is an index that reflects salt content of soils, which was higher in both sludge treatments than in the fertilizer control (Table 2). We speculate that water extracts may contain some soluble salts and organic carbon promoting the luminescence of $P$. phosphoreum T3. However, the nontoxicity of water extracts does not demonstrate that sludge amendment of the soil resulted in no biological toxicity. Given the hydrophobicity of major organic contaminant PAHs mentioned above, DMSO was selected as the most suitable solvent for chemical compounds with low aqueous solubility due to its good properties and low toxicity to P. phosphoreum (Dong et al. 2013). The relative luminosity of DMSO extracts from the petrochemical sludge treatment was significantly lower, that is to say the biological toxicity of soil receiving petrochemical sludge was much higher than those of the other two treatments. This may result from the accumulation of PAHs and/or other unknown toxic waterinsoluble substances. In short, the results suggest that petrochemical sewage sludge may represent a greater potential hazard than domestic sewage sludge in agriculture because of its high PAH content and consequent biological toxicity.

The activity of the soil microbial community evaluated by AWCD was always higher in domestic sludge-treatment soil than the other two treatments and the overall trend showed the AWCD sequence domestic sludge $>$ petrochemical sludge $>$ fertilizer control after $96 \mathrm{~h}$ (Fig. 3), indicating positive effects of the two sewage sludge types on soil microbial activity. One explanation may be that organic matter and nutrients in the sludge play an important role in promoting soil microbial activity. On the other hand, the sequencing data show that microbial richness and diversity changed only slightly in the sludge amended soil compared with the fertilizer control (Table 3). Comparison at the phylum level shows that the bacteria was very similar (Fig. 4). High PAH concentrations can lead to substantial changes in microbial community structure and diversity as shown in previous studies (Sawulski et al. 2014) but their effects were comparatively small in the current experiment. This might be attributed to a dilution effect in paddy fields when the sewage sludges were applied to relatively large areas of agricultural land and to the degradation of indigenous microorganisms in the soil. However, several genera were enriched in soil receiving the petrochemical sludge, including Desulfomonile, Mycobacterium, Nocardioides, and Sphingomonas (Fig. 5). Desulfomonile, a member of the $\delta$ proteobacteria, is common in oilfield wastewater and is known to acidify fossil oils with the production of noxious $\mathrm{H}_{2} \mathrm{~S}$ gas (Rueter et al. 1994). The genus Mycobacterium belongs to the Actinobacteria, is a Gram-positive heterotrophic bacterium, and has been reported to be capable of degrading a wide range of PAHs, not only high-molecular-weight but also low-molecular-weight PAHs (Wick et al. 2002; Zeng et al. 2010). Other genera (Sphingomonas and Nocardioides) have also been reported to be involved in PAH degradation (Saito et al. 2000; Demaneche et al. 2004; Schippers et al. 2005; Desai et al. 2008; Zeinali et al. 2008). The changes in the composition, structure, and diversity of the soil microbial community may result from the combined effects of soil quality, nutrient content, and various pollutants that have accumulated in the soil.

\section{Conclusions}

The influence repeated applications of different types of sewage sludge on soil fertility, pollutant accumulation, biological toxicity, and microbial community were studied. Soil organic matter and total nitrogen contents in the two sludge treatments were significantly higher than in the plots receiving chemical fertilizer after 5 years of sludge amendment. Sludge application showed no significant influence on potentially toxic metals but contents of PAHs, and especially high-molecularweight PAHs (five-, six-rings) were significantly higher $(p<0.05)$ in the petrochemical sludge treatment. Because of the hydrophobicity of the accumulating PAHs, DMSO was selected as extraction solvent to assess the biological toxicity of the soil and it was found that the biological toxicity of soil DMSO extracts from the petrochemical sludge treatment was substantially higher than those of the other treatments $(p<0.05)$. Furthermore, Biolog carbon utilization and highthroughput pyrosequencing indicated that amendment with both types of sludge increased soil microbial activity but there was no significant influence on bacterial community diversity indices, although some genera related to $\mathrm{PAH}$ degradation were enriched in the petrochemical sludge treatment. Overall, petrochemical sewage sludge seemed to represent a higher potential hazard than domestic sewage sludge in agricultural application because of its high PAH content, and biological toxicity and monitoring programs must be developed to evaluate the long-term impacts of repeated sludge applications in conventional agriculture.

Acknowledgements We thank the National Natural Science Foundation of China (41671325) and the Key Research Program of the Chinese Academy of Sciences (KFZD-SW-303) for financial support.

\section{References}

Asagi N, Ueno H (2008) Determination of application effects of sewage sludge on growth, soil properties, and $\mathrm{N}$ uptake in Komatsuna by using the indirect $15 \mathrm{~N}$ isotope method. Commun Soil Sci Plant Anal 39:1928-1942 
Bondarczuk K, Markowicz A, Piotrowska-Seget Z (2016) The urgent need for risk assessment on the antibiotic resistance spread via sewage sludge land application. Environ Int 87:49-55

Boonchan S, Britz ML, Stanley GA (2000) Degradation and mineralization of high-molecular-weight polycyclic aromatic hydrocarbons by defined fungal-bacterial cocultures. Appl Environ Microbiol 66: $1007-1019$

Cai QY, Mo CH, Wu QT, Zeng QY, Katsoyiannis A (2007) Occurrence of organic contaminants in sewage sludges from eleven wastewater treatment plants, China. Chemosphere 68:1751-1762

Chen H, Yan SH, Ye ZL, Meng HJ, Zhu YG (2012) Utilization of urban sewage sludge: Chinese perspectives. Environ Sci Pollut Res 19: 1454-1463

Cheng M, Wu L, Huang Y, Luo Y, Christie P (2014) Total concentrations of heavy metals and occurrence of antibiotics in sewage sludges from cities throughout China. J Soils Sediments 14:1123-1135

Demaneche S, Meyer C, Micoud J, Louwagie M, Willison JC, Jouanneau Y (2004) Identification and functional analysis of two aromaticring-hydroxylating dioxygenases from a Sphingomonas strain that degrades various polycyclic aromatic hydrocarbons. Appl Environ Microbiol 70:6714-6725

Desai AM, Autenrieth RL, Dimitriou-Christidis P, McDonald TJ (2008) Biodegradation kinetics of select polycyclic aromatic hydrocarbon (PAH) mixtures by Sphingomonas paucimobilis EPA505. Biodegradation 19:223-233

Ding S, Wu J, Zhang M, Lu H, Mahmood Q, Zheng P (2015) Acute toxicity assessment of ANAMMOX substrates and antibiotics by luminescent bacteria test. Chemosphere 140:174-183

Dong YY, Wang J, Ding L, Liu YY (2013) Influence of cosolvents on low water-solubility chemicals to Photobacterium phosphoreum in acute toxicity test. Procedia Environmental Sciences 18:143-148

Duan B, Liu F, Zhang W, Zheng H, Zhang Q, Li X, Bu Y (2015) Evaluation and source apportionment of heavy metals (HMs) in sewage sludge of municipal wastewater treatment plants (WWTPs) in Shanxi, China. Inter J Env Res Pub Heal 12:1580715818

Fliessbach A, Martens R, Reber HH (1994) Soil microbial biomass and microbial activity in soils treated with heavy metal contaminated sewage sludge. Soil Biol Biochem 26:1201-1205

Fullana A, Conesa JA, Font R, Sidhu S (2004) Formation and destruction of chlorinated pollutants during sewage sludge incineration. Environ Sci Technol 38:2953-2958

Garland JL, Mills AL (1991) Classification and characterization of heterotrophic microbial communities on the basis of patterns of community-level sole-carbon-source utilization. Appl Environ Microbiol 57:2351-2359

Harder R, Peters GM, Svanström M, Khan SJ, Molander S (2016) Estimating human toxicity potential of land application of sewage sludge: the effect of modelling choices. Int J Life Cycle Assess, pp: 1-13. doi:10.1007/s11367-016-1182-x

Hou J, Liu W, Wang B, Wang Q, Luo Y, Franks AE (2015) PGPR enhanced phytoremediation of petroleum contaminated soil and rhizosphere microbial community response. Chemosphere 138:592598

IARC (1983) Monographs on the evaluation of the carcinogenic risk of chemicals to humans. Vol. 32. Polynuclear aromatic compounds, Part 1: Chemical, environmental and experimental data. International Agency for Research on Cancer. Lyon: France

Kelessidis A, Stasinakis AS (2012) Comparative study of the methods used for treatment and final disposal of sewage sludge in European countries. Waste Manag 32:1186-1195

Li H, Wu WX, Liu YX, Tientchen CM, Chen YX (2008) Heavy metals and PAHs in sewage sludge from twelve wastewater treatment plants in Zhejiang Province. Biomed Environ Sci 21:345-352

Lichtfouse E, Sappin-Didier V, Denaix L, Caria G, Metzger L, AmellalNassr N, Schmidt J (2005) A 25-year record of polycyclic aromatic hydrocarbons in soils amended with sewage sludges. Environ Chem Lett 3:140-144

Liu JY, Sun SY (2013b) Total concentrations and different fractions of heavy metals in sewage sludge from Guangzhou, China. Trans Nonferrous Met Soc China 23:2397-2407

Liu W, Jiang JG, Shi GY, He Y, Liu Y, Jin LT (2007) Toxicity assessment of cyanide and tetramethylene disulfotetramine (tetramine) using luminescent bacteria Vibrio-qinghaiensis and $\mathrm{PbO}_{2}$ electrochemical sensor. Chin J Chem 25:203-207

Liu C, Li K, Yu L, Xu Y, Huang B, Wu J, Wang Z (2013a) POPs and their ecological risk in sewage sludge of waste water treatment plants in Beijing, China. Stochastic Environmental Research and Risk Assessment 27:1575-1584

Liu W, Wang B, Wang Q, Hou J, Wu L, Wood JL, Luo Y, Franks AE (2016) Characteristics of metal-tolerant plant growth-promoting yeast (Cryptococcus sp. NSE1) and its influence on Cd hyperaccumulator Sedum plumbizincicola. Environ Sci Pollut Res 23:18621-18629

Lu RK (1999) Analytical methods of soil agricultural chemistry. China Agriculture Science and Technology Press, Beijing (in Chinese)

Mahapatra K, Ramteke DS, Paliwal LJ, Naik NK (2013) Agronomic application of food processing industrial sludge to improve soil quality and crop productivity. Geoderma 207:205-211

Mardan S, Ebrahimi A, Amin MM, Momeni SA, Ghodousi H, Adineh MA (2015) Heavy metals and polycyclic aromatic hydrocarbons in sludge from three industrial wastewater treatment plants of the industrial parks of Isfahan province. Int J Env Health Eng 4:32. doi:10. 4103/2277-9183.163976

National Research Council (2002) Biosolids applied to land: advancing standards and practices. National Academic Press, Washington, DC

Oleszczuk P (2006) Persistence of polycyclic aromatic hydrocarbons (PAHs) in sewage sludge-amended soil. Chemosphere 65:16161626

Oleszczuk P, Baran S (2005) Influence of soil fertilization by sewage sludge on the content of polycyclic aromatic hydrocarbons (PAHs) in crops. J Environ Sci Health 40:2085-2103

Pritchard DL, Penney N, McLaughlin MJ, Rigby H, Schwarz K (2010) Land application of sewage sludge (biosolids) in Australia: risks to the environment and food crops. Water Sci Technol 62:48-57

Roig N, Sierra J, Martí E, Nadal M, Schuhmacher M, Domingo JL (2012) Long-term amendment of Spanish soils with sewage sludge: effects on soil functioning. Agric Ecosyst Environ 158:41-48

Rueter P, Rabus R, Wilkes H, Aeckersberg F, Rainey FA, Jannasch HW, Widdel F (1994) Anaerobic oxidation of hydrocarbons in crude oil by new types of sulphate-reducing bacteria. Nature 372:455-458

Saito A, Iwabuchi T, Harayama SA (2000) A novel phenanthrene dioxygenase from Nocardioides sp. strain KP7: expression in Escherichia coli. J Bacteriol 182:2134-2141

Sawulski P, Clipson N, Doyle E (2014) Effects of polycyclic aromatic hydrocarbons on microbial community structure and $\mathrm{PAH}$ ring hydroxylating dioxygenase gene abundance in soil. Biodegradation 25:835-847

Schippers A, Schumann P, Spröer C (2005) Nocardioides oleivorans sp. nov., a novel crude-oil-degrading bacterium. Int J Syst Evol Microbiol 55:1501-1504

Schloss PD, Westcott SL, Ryabin T, Hall JR, Hartmann M, Hollister EB, Lesniewski RA et al (2009) Introducing mothur: open-source, platform-independent, community-supported software for describing and comparing microbial communities. Appl Environ Microbiol 75:7537-7541

Singh RP, Agarwal M (2008) Potential benefits and risks of land application of sewage sludge. Waste Manag 28:347-358

Stasta P, Boran J, Bebar L, Stehlik P, Oral J (2006) Thermal processing of sewage sludge. Appl Therm Eng 26:1420-1426 
Su J, Wang H, Kimberley MO, Beecroft K, Magesan GN, Hu C (2007) Fractionation and mobility of phosphorus in a sandy forest soil amended with biosolids. Environ Sci Pollut Res 14:529-535

Teng Y, Shen Y, Luo Y, Sun X, Sun M, Fu D, Li Z, Christie P (2011) Influence of Rhizobium meliloti on phytoremediation of polycyclic aromatic hydrocarbons by alfalfa in an aged contaminated soil. J Hazard Mater 186:1271-1276

Udom BE, Mbagwu JSC, Adesodun JK, Agbim NN (2004) Distributions of zinc, copper, cadmium and lead in a tropical ultisol after longterm disposal of sewage sludge. Environ Int 30:467-470

Ulitzur S, Lahav T, Ulitzur N (2002) A novel and sensitive test for rapid determination of water toxicity. Environ Toxicol 17:291-296

Usman K, Khan S, Ghulam S, Khan MU, Khan N, Khan MA, Khalil SK (2012) Sewage sludge: an important biological resource for sustainable agriculture and its environmental implications. Am J Plant Sci 3:1708-1721

Wang X, Chen T, Ge Y, Jia Y (2008) Studies on land application of sewage sludge and its limiting factors. J Hazard Mater 160:554-558
Wick L, De Munain A, Springael D, Harms H (2002) Responses of Mycobacterium sp. LB501T to the low bioavailability of solid anthracene. Appl Microbiol Biotechnol 58:378-385

Witter E, Gong P, Bååth E, Marstorp H (2000) A study of the structure and metal tolerance of the soil microbial community six years after cessation of sewage sludge applications. Environ Toxicol Chem 19: 1983-1991

Wu L, Cheng M, Li Z, Ren J, Shen L, Wang S, Luo Y, Christie P (2012) Major nutrients, heavy metals and PBDEs in soils after long-term sewage sludge application. J Soils Sediments 12:531-541

Zeinali M, Vossoughi M, Ardestani SK (2008) Naphthalene metabolism in Nocardia otitidiscaviarum strain TSH1, a moderately thermophilic microorganism. Chemosphere 72:905-909

Zeng J, Lin X, Zhang J, Li X (2010) Isolation of polycyclic aromatic hydrocarbons (PAHs)-degrading Mycobacterium spp. and the degradation in soil. J Hazard Mater 183:718-723 